\title{
Association between physical inactivity in leisure, work, commuting, and household domains and nutritional status in adults in the capital cities of Brazil
}

\author{
Associação entre a inatividade física nos \\ dominios do lazer, trabalho, deslocamento \\ e domicílio e o estado nutricional \\ em adultos das capitais do Brasil
}

\author{
Anne Ribeiro STREB ${ }^{1}$ (ID) 0000-0001-9195-4210 \\ Thiago Sousa MATIAS1 (ID) 0000-0003-0241-3776 \\ Larissa dos Santos LEONEL1 (iD) 0000-0002-5778-055X \\ Willen Remon TOZETTO1 ${ }^{1}$ (D) 0000-0001-8856-1678 \\ Carolina Graef VIEIRA ${ }^{1}$ iD 0000-0002-6902-0275 \\ Giovani Firpo DEL DUCA ${ }^{1}$ iD 0000-0003-0893-2032
}

\section{A B S T R A C T}

\section{Objective}

To investigate the association between different domains (leisure, work, commuting, and household) of physical activity, independent and cumulative, and excess weight and obesity in Brazilian adults.

\footnotetext{
${ }^{1}$ Universidade Federal de Santa Catarina, Centro de Desportos, Departamento de Educação Física. R. Eng. Agronômico Andrei Cristian Ferreira, s/n., Trindade, 88040-900, Florianópolis, SC, Brasil. Correspondence to: GF DEL DUCA. E-mail: <gfdelduca@gmail.com>.

Support: This study was financed in part by the Coordenação de Aperfeiçoamento de Pessoal de Nivel Superior (Finance Code 001).
}

\footnotetext{
How to cite cite this article

Streb AR, Matias TS, Leonel LS, Tozetto WR, Vieira CG, Del Duca GF. Association between physical inactivity in leisure, work, commuting, and household domains and nutritional status in adults in the capital cities of Brazil. Rev Nutr. 2019;32:e180276. http://dx.doi.org/10.1590/1678-9865201932e180276
} 


\section{Methods}

This is a cross-sectional survey, conducted in 2015, through telephone interviews with a representative sample of adults from the capitals of Brazil. Physical inactivity was defined as non-participation in predefined physical activities for each assessed domain. Excess weight (Body Mass Index $\geq 25 \mathrm{~kg} / \mathrm{m}^{2}$ ) and obesity (Body Mass Index $\geq 30 \mathrm{~kg} / \mathrm{m}^{2}$ ) were determined from self-reported measurements of weight and height. A binary logistic regression was conducted after adjusting for sociodemographic factors.

\section{Results}

Among 54,174 subjects, physical inactivity in commuting $\left(O R_{\text {excess weight }}=1.27,95 \% \mathrm{Cl}=1.13,1.42\right.$ and $O R_{\text {obesity }}=1.25$, $95 \% \mathrm{Cl}=1.06,1.47)$ and leisure $\left(\mathrm{OR}_{\text {excess weight }}=1.12,95 \% \mathrm{Cl}=1.04,1.22\right.$ and $\left.\mathrm{OR}_{\text {obesity }}=1.30,95 \% \mathrm{Cl}=1.17,1.45\right)$ domains were associated with nutritional status. In addition, a linear trend was observed between increasing obesity and cumulative physical inactivity of all four domains $(p<0.001)$.

\section{Conclusion}

Cumulative physical inactivity, especially in the commuting and leisure domains, was associated with excess weight and obesity in adults living in the capitals of Brazil. One possible explanation of these findings is that these domains involve particularly longer duration and greater intensity of physical inactivity. Public policies concerning physical activity should prioritize actions focused in promoting physical activity on commuting and leisure-time to help prevent overweight and obesity in the Brazilian adult population.

Keywords: Body Mass Index. Leisure activities. Motor activity. Nutritional status.

\section{R E S U M O}

\section{Objetivo}

Investigar a associação entre a atividade física em diferentes domínios (deslocamento, domicilio, lazer e trabalho) isolados e acumulados com a ocorrência de excesso de peso e obesidade em adultos brasileiros.

\section{Métodos}

Trata-se de um inquérito transversal, realizado em 2015, por meio de entrevista telefônica com uma amostra representativa de adultos das capitais do Brasil. A inatividade física foi determinada como a não participação em atividades físicas específicas para cada domínio avaliado. O excesso de peso (Índice de Massa Corporal $\geq 25 \mathrm{~kg} / \mathrm{m}^{2}$ ) e a obesidade (Índice de Massa Corporal $\geq 30 \mathrm{~kg} / \mathrm{m}^{2}$ ) foram definidos pelo autorrelato de peso e altura. Na estatística, empregou-se a regressão logística binária ajustada para fatores sociodemográficos.

\section{Resultados}

Dentre os 54.174 sujeitos, observou-se que a inatividade física no deslocamento (OR=1,27; IC95\%:1,13;1,42 e $O R=1,25$; IC95\%:1,06;1,47) e no lazer (OR=1,12; IC95\%:1,04;1,22 e OR=1,30; IC95\%:1,17;1,45) estiveram associadas ao excesso de peso e à obesidade, respectivamente. Observou-se ainda uma tendência linear de aumento da obesidade à medida que se acumulam domínios com inatividade física $(p<0,001)$.

\section{Conclusão}

A inatividade física acumulada em diferentes domínios, particularmente no deslocamento e no lazer, apresentou associação com o excesso de peso e obesidade em adultos residentes nas capitais do Brasil. Possivelmente, importantes características da atividade física nos referidos domínios, como a maior duração e a maior intensidade, sejam potenciais justificativas para o encontro de tais achados. Portanto, recomenda-se que politicas públicas de atividade física possam priorizar ações voltadas para os domínios do deslocamento e do lazer no combate ao excesso de peso e obesidade na população adulta brasileira.

Palavras-chave: Índice de Massa Corporal. Atividades de lazer. Atividade motora. Estado nutricional.

\section{NTROD U C T I O N}

Physical inactivity is one of the most common, persistent, and important contributors to poor health; adoption of inactive lifestyles in diverse populations world-wide indicates that campaigns promoting physical activity have been unsuccessful [1]. According to estimates by the Global Health 
Observatory, an initiative led by the World Health Organization (WHO), $23 \%$ of men and $32 \%$ of women over 18 years of age are physically inactive [2]. Furthermore, globally in 2016, an estimated $39 \%$ of adults were overweight and $13 \%$ were obese [3].

New paradigms for the reduction of physical inactivity are fundamental. There is a need to understand how the individual domains of physical activity interact with health. Evidence suggests that the practice of physical activity in leisure promotes health benefits, including physical and mental well-being and the maintenance of a healthy body weight [4]. However, the relationship of other physical activity domains, such as physical activity at work, has presented controversial evidence regarding benefits to health [5-7].

The conditions that impede or favor the adoption of a physically active lifestyle can vary based on country and culture [8]. Consequently, studies have shown that the health benefits associated with the individual domains of physical activity can show significant discrepancies and are highly dependent on environmental context $[9,10]$. Recent evidence in Brazil establishes that both the practice of physical activity in leisure and the percentage of Brazilians attaining the recommended levels of physical activity have increased [11]. Yet, in the period of approximately a decade, a notable increase in indicators of excess weight [12], suggests poor management of body mass.

It is important to consider that the domains of physical activity are not independent, and instead are related through complex interactions. As such, the level of physical activity in one domain may strongly influence the level of physical activity in the others [8,9]. Analyzing the domains of physical inactivity may also contribute to the broader conceptualization of health [13]. In this way, physical activity can be used to better understand the weight status of Brazilians and guide prevention interventions to address the alarming pandemic of obesity in Brazil. This study aims to investigate the association between different domains (leisure, work, commuting, and household) of physical inactivity, independent and cumulative, and excess weight and obesity in Brazilian adults.

\section{METHODS}

This study used a population-based cross-sectional design. Data were extracted from databases, obtained from the Vigilância de Fatores de Risco e Proteção para Doenças Crônicas por Inquérito Telefônico (VIGITEL, Vigilance of Risk Factors and Protection of Chronic Diseases by Telephone Inquiry). A telephone interview was conducted in 2015 whereby adult men and women ( $\geq 18$ years old) were interviewed who had a fixed telephone line and who resided in one of the 26 Brazilian capitals or in the Federal District. The sample of the population was selected from each studied city's registers of fixed telephone lines. Each register was systematically drawn from 5,000 telephone lines, of which at least 2,000 lines were selected according to the postal code. The interviews were carried out by a specialized company and the interviewers applied a previously validated questionnaire [14]. The answers to the questionnaire were recorded in an electronic database. More detailed information concerning the sampling process and the questionnaire utilized are reported in the original VIGITEL report [15].

Body Mass Index (BMI) was calculated using interviewees' self-reported measures of weight in kilograms and height in meters squared. Missing data were imputed using the hot deck technique. 
BMI values defined as being excess weight or obese were $\geq 25 \mathrm{~kg} / \mathrm{m}^{2}$ and $\geq 30 \mathrm{~kg} / \mathrm{m}^{2}$, respectively. Furthermore, physical inactivity was defined as not participating in specified physical activities for each domain. In the leisure domain, not engaging in any physical exercise and/or sport within the previous three months was considered inactive. Inactivity within the domain of commuting was defined as not using walking or cycling as a mode of transportation for school, travel or work. Inactivity at home was classified as not being involved in heavy household work. At work, individuals who did not carry weight and/or did not walk during work activities were considered inactive. The sum of physical inactivity was calculated by using a combination of the four domains of physical activity and was categorized into: Inactive in none, one, two, three, or all domains, independently of the domain evaluated. The sociodemographic factors of sex (male vs. female), age (in complete years), and schooling (categorized as 0 to 8,9 to 11 , and $\geq 12$ years of study) were utilized as confounding variables and controlled for in subsequent analysis.

For each variable investigated, descriptive analysis was reported, including the absolute (n), and relative (\%) frequencies of the variables with a $95 \%$ Confidence Interval $(95 \% \mathrm{Cl})$. We conducted a binary logistic regression analysis, with hierarchical adjustment, to quantify the association between nutritional status and either the individual domains of physical activity or the sum of the domains. In the hierarchical adjustment, the first level comprised of sex and age, and the second level consisted of schooling and the other domains. The significance level was $p$-value $\leq 0.05$. All analyses were performed using statistical software Stata ${ }^{\circledR}$ Standard Edition, version 15.0 (Stata Corp., College Station, Texas, United States). Data weighting and complex sampling were taken into account.

Participants consented verbally via phone call to participating in this study. VIGITEL was approved by the National Commission for Ethics in Research for Human Subjects, of the Ministry of Health, with the opinion No.749/2006 and the registry No.13.081.

\section{R E S U L T S}

Among 76,703 subjects who were eligible for this study, 54,174 adults were interviewed (70.6\%). Table 1 describes the sociodemographic characteristics, domain-specific physical inactivity, and excess weight and obesity within the sample population. Over half of participants were women (54.0\%; 95\%Cl:53.1;54.9). The mean age of interviewees was $47.5( \pm 17.5)$ years. Approximately $35.0 \%(95 \% \mathrm{Cl}: 33.6 ; 35,5)$ of participants were schooled up to eight years. The majority of the sample population were considered inactive in the commuting $(85.9 \% ; 95 \% \mathrm{Cl}: 87.3 ; 88.7)$, household (58.4\%; 95\% Cl: 57.5;59.3), and work (62.2\%; 95\% Cl:61.2;63.1) domains. Moreover, in the leisure domain, physical inactivity was present in $48.8 \%(95 \% \mathrm{Cl}: 47.8 ; 49.7)$ interviewees. Over $52.0 \%(95 \% \mathrm{Cl}: 53.0 ; 54.8)$ of the participants were excess weight, while $18.9 \%$ (95\%Cl:18.2;19.7) were obese.

Table 2 demonstrates how physical inactivity within the four domains is associated with being excess weight in adults living in the capitals of Brazil. In the sociodemographic adjusted analysis, physical inactivity in the commuting (Odds Ratio $[\mathrm{OR}]=1.27,95 \% \mathrm{Cl}: 1.13 ; 1.42)$ and leisure $(\mathrm{OR}=1.12$, 
Table 1. Sociodemographic characteristics, domain-specific physical inactivity, and nutritional status of adults living in Brazilian capitals. Brazil, 2015.

\begin{tabular}{|c|c|c|c|}
\hline \multirow{2}{*}{ Variable } & \multicolumn{3}{|c|}{$n=54,174$} \\
\hline & $n$ & $\%^{a}$ & $95 \% \mathrm{Cl}$ \\
\hline \multicolumn{4}{|l|}{ Sex } \\
\hline Men & 20,368 & 46.0 & $(45.1 ; 47.0)$ \\
\hline Women & 33,806 & 54.0 & $(53.0 ; 54.9)$ \\
\hline \multicolumn{4}{|c|}{ Schooling (years) } \\
\hline 0 to 8 & 14,924 & 34.6 & $(33.6 ; 35.5)$ \\
\hline 9 to 11 & 19,525 & 38.1 & $(37.2 ; 39.0)$ \\
\hline$\geq 12$ & 19,725 & 27.3 & $(26.5 ; 28.1)$ \\
\hline \multicolumn{4}{|c|}{ Physical Inactivity in work } \\
\hline No & 16,239 & 37.8 & $(36.9 ; 38.7)$ \\
\hline Yes & 37,656 & 62.2 & $(61.2 ; 63.1)$ \\
\hline \multicolumn{4}{|c|}{ Physical Inactivity in household } \\
\hline No & 22,288 & 41.6 & $(40.7 ; 42.5)$ \\
\hline Yes & 31,886 & 58.4 & $(57.5 ; 59.3)$ \\
\hline \multicolumn{4}{|c|}{ Physical Inactivity in commuting } \\
\hline No & 5,380 & 14.1 & $(13.4 ; 14.7)$ \\
\hline Yes & 48,678 & 85.9 & $(85.2 ; 86.6)$ \\
\hline \multicolumn{4}{|c|}{ Physical Inactivity in leisure } \\
\hline No & 28,938 & 51.2 & $(50.3 ; 52.2)$ \\
\hline Yes & 25,236 & 48.8 & $(47.8 ; 49.7)$ \\
\hline \multicolumn{4}{|c|}{ Excess weight } \\
\hline No & 23,993 & 46.1 & $(45.1 ; 47.0)$ \\
\hline Yes & 30,181 & 53.9 & $(53.0 ; 54.8)$ \\
\hline \multicolumn{4}{|l|}{ Obesity } \\
\hline No & 43,830 & 81.1 & $(80.3 ; 81.8)$ \\
\hline Yes & 10,344 & 18.9 & $(18.2 ; 19.7)$ \\
\hline
\end{tabular}

Note: n: absolute frequency; \%a. relative frequency for weighted sample; $95 \% \mathrm{Cl}$ : 95\% Confidence Interval.

$95 \% \mathrm{Cl}: 1.04 ; 1.22)$ domains was associated with being excess weight. In addition, inactive adults in the household domain were less likely to be excess weight compared to their peers $(O R=0.79$, $95 \% \mathrm{Cl}: 0.72 ; 0.86)$.

Table 3 demonstrates the association between physical inactivity within the four domains and obesity in adults living in the capitals of Brazil. In the adjusted analysis, it was observed that physical inactivity in the commuting $(\mathrm{OR}=1.25,95 \% \mathrm{Cl}: 1.06 ; 1.47)$ and leisure $(\mathrm{OR}=1.30,95 \% \mathrm{Cl}: 1.17 ; 1.45)$ domains were associated with obesity.

Figures 1 and 2 establish the aggregate physical inactivity within the four domains relates to excess weight and obesity in adults in the Brazilian capitals. A linear trend of increased obesity was observed as physical inactivity accumulated in the four domains $(p<0.001)$. 
Table 2. Domain-specific physical inactivity and its association with excess weight in adults living in the capitals cities of Brazil, 2015 $(n=54,174)$.

\begin{tabular}{|c|c|c|c|c|c|}
\hline \multirow{2}{*}{ Variable } & \multirow{2}{*}{$\frac{\text { Excess weight }}{\%^{\mathrm{a}}}$} & \multicolumn{2}{|c|}{ Crude analysis } & \multicolumn{2}{|c|}{ Adjusted analysis } \\
\hline & & OR $(95 \% \mathrm{Cl})$ & $P$ value & OR $(95 \% \mathrm{Cl})$ & $P$ value \\
\hline Physical Inactivity in commuting & & & $<0.001$ & & $<0.001$ \\
\hline No & 12.3 & 1.00 & & 1.00 & \\
\hline Yes & 87.7 & $1.37(1.22 ; 1.53)$ & & $1.27(1.13 ; 1.42)$ & \\
\hline Physical Inactivity in household & & & $<0.001$ & & $<0.001$ \\
\hline No & 43.1 & 1.00 & & 1.00 & \\
\hline Yes & 56.9 & $0.87(0.81 ; 0.94)$ & & $0.79(0.72 ; 0.86)$ & \\
\hline Physical Inactivity in leisure & & & $<0.001$ & & 0.004 \\
\hline No & 49.1 & 1.00 & & 1.00 & \\
\hline Yes & 50.9 & $1.21(1.12 ; 1.30)$ & & $1.12(1.04 ; 1.22)$ & \\
\hline Physical Inactivity in work & & & 0.030 & & 0.343 \\
\hline No & 38.8 & 1.00 & & 1.00 & \\
\hline Yes & 61.2 & $0.92(0.84 ; 0.99)$ & & $0.96(0.88 ; 1.04)$ & \\
\hline
\end{tabular}

Note: ${ }^{2}$ relative frequency for weighted sample; OR: Odds Ratio; 95\%Cl:95\% Confidence Interval.

$P$ value obtained by binary logistic regression. Analysis adjusted by hierarchical model, being the first level the sex and age the second level the schooling and the other domains.

Table 3. Association between physical inactivity in different domains and obesity in adults living in the capitals cities of Brazil, 2015 $(n=54,174)$.

\begin{tabular}{|c|c|c|c|c|c|}
\hline \multirow{2}{*}{ Variable } & \multirow{2}{*}{$\frac{\text { Obesity }}{\%^{a}}$} & \multicolumn{2}{|c|}{ Crude analysis } & \multicolumn{2}{|c|}{ Adjusted analysis } \\
\hline & & OR $(95 \% \mathrm{Cl})$ & $P$ value & OR $(95 \% \mathrm{Cl})$ & $P$ value \\
\hline Physical Inactivity in commuting & & & $<0.001$ & & 0.006 \\
\hline No & 11.5 & 1.00 & & 1.00 & \\
\hline Yes & 88.5 & $1.33(1.13 ; 1.55)$ & & $1.25(1.06 ; 1.47)$ & \\
\hline Physical Inactivity in household & & & $<0.001$ & & 0.065 \\
\hline No & 44.7 & 1.00 & & 1.00 & \\
\hline Yes & 55.3 & $0.85(0.77 ; 0.94)$ & & $0.91(0.83 ; 1.04)$ & \\
\hline Physical Inactivity in leisure & & & $<0.001$ & & $<0.001$ \\
\hline No & 43.7 & 1.00 & & 1.00 & \\
\hline Yes & 56.3 & $1.45(1.31 ; 1.61)$ & & $1.30(1.17 ; 1.45)$ & \\
\hline Physical Inactivity in work & & & 0.003 & & 0.164 \\
\hline No & 36.8 & 1.00 & & 1.00 & \\
\hline Yes & 63.2 & $1.05(94.7 ; 1.17)$ & & $1.09(0.97 ; 1.22)$ & \\
\hline
\end{tabular}

Note: arelative frequency for weighted sample; OR: Odds Ratio; 95\%Cl: 95\% Confidence Interval.

$P$ value obtained by binary logistic regression. Analysis adjusted by hierarchical model, being the first level the sex and age the second level the schooling and the other domains. 


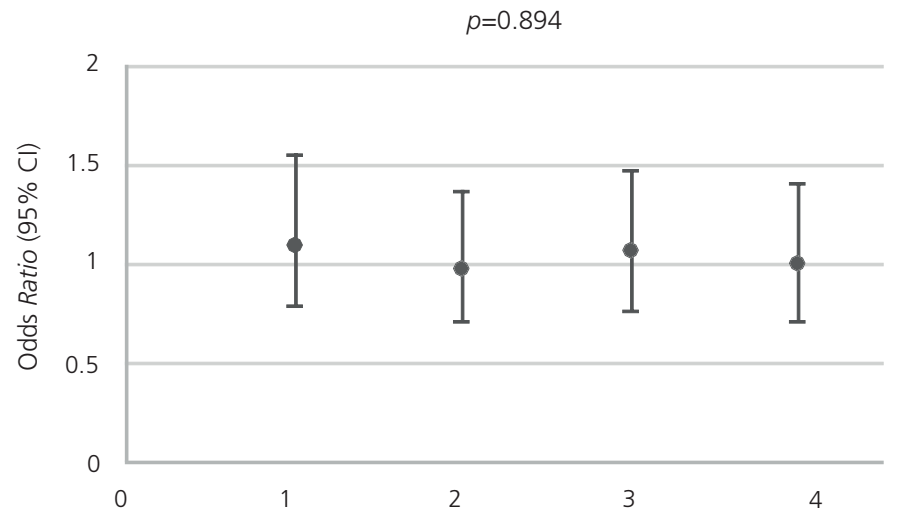

Figure 1. Aggregated association between physical inactivity and excess weight in adults living in the capitals cities of Brazil, 2015.

$p<0.01$

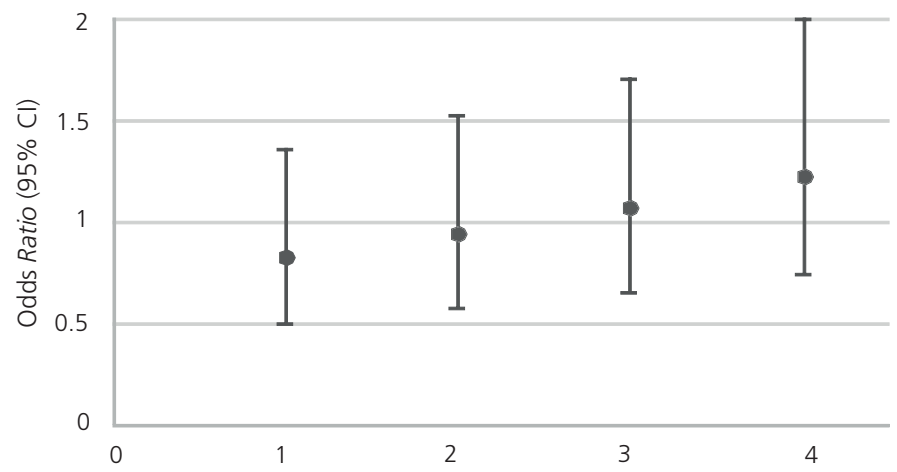

Figure 2. Aggregated association between physical inactivity and obesity in adults living in the capitals cities of Brazil, 2015.

\section{I S C USSIO N}

The present study investigated the association between of physical inactivity in leisure, work, commuting, and household and excess weight and obesity in Brazilian adults. One possible explanation of our findings is that a sedentary lifestyle is associated with physical inactivity in commuting and leisure domains, thereby causing excess weight and obesity in adults. This interpretation is supported by experimental evidence which indicates that leisure-specific physical inactivity is related to an increased adiposity $[16,17]$. In addition, inactive commuting has been reported to inhibit both general health benefits [18] and an improved body composition [19].

Commuting-specific physical inactivity was present in $85.9 \%$ of study participants and increased the odds of being excess weight. Consequently, public health policies which focus on increasing active commuting, are critical. Advantageously, active commuting is accessible, and is particularly common in low- and middle-income countries [20,21]. Walking and cycling are ideal ways for people to incorporate more physical activity in their daily routines [22]. Unfortunately, in Brazil, active commuting is still not as culturally accepted, in part as a result of its association with lower socioeconomic levels and social status [23-25]. An additional challenge in Brazil is the feeling of insecurity, which can reduce the time spent travelling, in spite of the health benefits 
associated with active commuting $[17,18]$. Moreover, there are numerous structural barriers, such as, a lack of bicycle lanes hindering accessibility [26]. However, those who manage to become active commuters demonstrate significant benefits in their health status, for example, have reduced risk for cardiovascular disease $[21,27]$.

Our results demonstrate that physical inactivity in leisure-time is positively associated with excess weight and obesity and is present in $50.9 \%$ of the excess weight population and $56.3 \%$ of those with obesity. This practice is strongly associated with body mass, in which those who practice activities of moderate/vigorous intensity in this field present positive results in their composition, helping to reduce and maintain the weight, corroborating to lower chances of triggering obesity $[16,28]$. Participating in leisure-time sports in adulthood leads to lower sedentary behavior in old age and therefore, a reduction in health problems, including obesity [29]. These studies highlight principal characteristics of physical activity in leisure-time, such as duration and intensity, that must be incorporated within the leisure domain so as to maximize the benefits of intentional practice.

We demonstrate that the sum of physical inactivity across the four activity domains increased the risk of obesity. Samitz et al. [4], demonstrate that increases in time spent in domain-specific physical activity (e.g., leisure) and total physical activity are associated with a reduction of all-cause mortality. Evidence confirms that increasing an individual's total time spent engaging in physical activity can protect against cardiovascular disease [30], in addition to being an important behavior for the positive regulation of pro-inflammatory and anti-inflammatory cytokines that may be related to obesity and diabetes [31].

While physical inactivity in the domains of commuting and leisure was associated with greater occurrences of both excess weight and obesity in the Brazilian adult population, the same cannot be observed for physical inactivity at household. In the present study, inactive individuals in the domestic environment were less likely to be excess weight. This result is quite conflicting with the literature. However, a likely explanation for this is the interaction between domains. A study of patterns of activity aggregation in different domains found a high possibility of subjects with high physical activity volume at leisure presenting low level of physical activity at household [32]. It is worth noting that, in our adjusted analysis, all domains are adjusted to each other, but the total volume of physical activity in each domain was not taken into account. The present analysis refers only to the dichotomy between whether or not to do some physical activity in each domain. In our database (unpublished results), we observed a direct association between physical inactivity at household and the reach of physical activity recommendations in leisure, which helps us elucidate the total volume of physical activity in each domain as a possible confounding factor in dichotomous analyzes.

Some limitations are present in this study. Eating behavior as well as time in sedentary behavior were not accounted in the present study. Furthermore, data analysis included individual domains rather than combining different active and inactive domains. In addition, there is the possibility of bias in the questionnaire regarding the self-reported values for weight, height, and physical activity. However, through the use of the VIGITEL procedures, the data collection is reliable. On the other hand, the use of procedures by VIGITEL that supervise and monitor the quality of the data and the constant training of the interviewers, with checks and audits in about $10 \%$ of the daily connections in random samples, guarantee reliability of the answers. Likewise, the sample size with the use of capital data, allows the results to be representative of the Brazilian adult population living in the capitals of Brazil with telephone line coverage. In this sense, the other cities in the country may present different prevalence of the variables evaluated, but the 
contribution of the evidence of the relation between the sum of physical inactivity in domains and the deleterious effects on health is plausible in the general population. Another point to be highlighted is the use of two categories linked to nutritional status, making possible different associations with inactivity.

\section{CONCLUSION}

It was concluded that physical inactivity accumulated across four domains (particularly commuting and leisure) is associated with excess weight and obesity among Brazilian adults from capital cities. Important physical activity characteristics in these domains, such as longer duration and greater intensity, are potential justifications for such findings. In order to design effective strategies to encourage physical activity, this study sought to identify which specific domains where Brazilian adults are more physically inactive; and thus, drivers of weight gain and obesity. Therefore, it is recommended that public health promotion policies should emphasize and stimulate voluntary participation in an active lifestyle. In addition, it is important to emphasize that specifically promoting physical activity in commuting and leisure are most effective in protecting against overweight and obesity among the Brazilian adult population.

\section{CONTRIBUTORS}

AR STREB, TS MATIAS and GF DEL DUCA participated in the study conception and design, data analysis and interpretation, article review, and approval of the final version. LS LEONEL, WR TOZETTO and CG VIEIRA participated in the study interpretation, article review, and approval of the final version.

\section{REFERE NCES}

1. Barreto PS. Why are we failing to promote physical activity globally? Bull World Health Organ. 2013;91(6):390A. http://dx.doi.org/10.2471/BLT.13.120790

2. World Health Organization. Prevalence of insufficient physical activity. Geneva: WHO; 2018 [cited 2018 Nov 13]. Available from: http://www.who.int/gho/ncd/risk_factors/physical_activity_text/en/

3. World Health Organization. Obesity and overweight. Geneva: WHO; 2018 [cited 2018 Nov 13]. Available from: http://www.who.int/news-room/fact-sheets/detail/obesity-and-overweight

4. Samitz G, Egger M, Zwahlen M. Domains of physical activity and all-cause mortality: Systematic review and dose-response meta-analysis of cohort studies. Int J Epidemiol. 2011;40(5):1382-400. http://dx.doi. org/10.1093/ije/dyr112

5. Bauman AE, Reis RS, Sallis JF, Wells JC, Loos RJF, Martin BW, et al. Correlates of physical activity: Why are some people physically active and others not? Lancet. 2012;380(9838):258-71. http://dx.doi.org/10.1016/S0 140-6736(12)60735-1

6. Holtermann A, Krause N, Van der Beek AJ, Straker L. The physical activity paradox: Six reasons why occupational physical activity (OPA) does not confer the cardiovascular health benefits that leisure time physical activity does. Br J Sports Med. 2018;52(3):149-50. http://dx.doi.org/10.1136/bjsports-2017-097965

7. White RL, Babic MJ, Parker PD, Lubans DR, Astell-Burt T, Lonsdale C. Domain-specific physical activity and mental health: A meta-analysis. Am J Prev Med. 2017;52(5):653-66. http://dx.doi.org/10.1016/j. amepre.2016.12.008

8. Del Duca GF, Garcia LMT, Silva SG, Silva KS, Oliveira ES, Barros MV, et al. Clustering of physical inactivity in leisure, work, commuting, and household domains: data from 47,477 industrial workers in Brazil. J Phys Act Health. 2015;12(9):1264-71. http://dx.doi.org/10.1123/jpah.2014-0309 
9. Bhatnagar P, Townsend N, Shaw A, Foster $C$. The physical activity profiles of South Asian ethnic groups in England. J Epidemiol Community Health. 2016;70(6):602-8. http://dx.doi.org/10.1136/jech-2015-206455

10. Beenackers MA, Kamphuis CB, Giskes K, Brug J, Kunst AE, Burdorf A, et al. Socioeconomic inequalities in occupational, leisure-time, and transport related physical activity among European adults: A systematic review. Int J Behav Nutr Phys Act. 2012;9(1):116. http://dx.doi.org/10.1186/1479-5868-9-116

11. Cruz MS, Bernal RTI, Claro RM. Trends in leisure-time physical activity in Brazilian adults (2006-2016). Cad Saúde Pública. 2018;34(10):e00114817. http://dx.doi.org/10.1590/0102-311x00114817

12. Malta DC, Santos MAS, Andrade SSCA, Oliveira TP, Stopa SR, Oliveira MM, et al. Tendência temporal dos indicadores de excesso de peso em adultos nas capitais brasileiras, 2006-2013. Ciênc Saúde Coletiva. 2016;21(4):1061-9. http://dx.doi.org/10.1590/1413-81232015214.12292015

13. Rovniak LS, Sallis JF, Saelens BE, Frank LD, Marshall SJ, Norman GJ, et al. Adults' physical activity patterns across life domains: Cluster analysis with replication. Health Psychol. 2010;29(5):496-505. http://dx.doi. org/10.1037/a0020428

14. Monteiro CA, Moura EC, Jaime PC, Lucca A, Florindo AA, Figueiredo ICR, et al. Monitoramento de fatores de risco para doenças crônicas por entrevistas telefônicas. Rev Saúde Pública. 2005;39(1):47-57. http://dx.doi. org/10.1590/S0102-311X2008000600013

15. Ministério da Saúde (Brasil). Vigitel Brasil 2015: vigilância de fatores de risco e proteção para doenças crônicas por inquérito telefônico: estimativas sobre frequência e distribuição sociodemográfica de de fatores de risco e proteção para doenças crônicas nas capitais dos 26 estados brasileiros e no Distrito Federal em 2015. Brasília: MS; 2016 [citado 10 dez 2018]. Disponível em: http://bvsms.saude.gov.br/bvs/publicacoes/ vigitel_brasil_2015.pdf

16. Du H, Bennett D, Li L, Whitlock G, Guo Y, Collins R, et al. Physical activity and sedentary leisure time and their associations with BMI, waist circumference, and percentage body fat in 0.5 million adults: The China Kadoorie Biobank study. Am J Clin Nutr. 2013;97(3):487-96. http://dx.doi.org/10.3945/ajcn.112.046854

17. Sarma S, Devlin RA, Gilliland J, Campbell MK, Zaric GS. The effect of leisure-time physical activity on obesity, diabetes, high BP and heart disease among Canadians: Evidence from 2000/2001 to 2005/2006. Health Econ. 2015;24(12):1531-47. http://dx.doi.org/10.1002/hec.3106

18. Mueller N, Rojas-Rueda D, Cole-Hunter T, Nazelle A, Dons E, Gerike R, et al. Health impact assessment of active transportation: A systematic review. Prev Med. 2015;76:103-14. http://dx.doi.org/10.1016/j. ypmed.2015.04.010

19. Flint $E$, Cummins $S$. Active commuting and obesity in mid-life: Cross-sectional, observational evidence from UK Biobank. Lancet Diabetes Endocrinol. 2016;4(5):420-35. http://dx.doi.org/10.1016/S2213-8587(16)00053-X

20. Celis-Morales CA, Lyall DM, Welsh P, Anderson J, Steell L, Guo Y, et al. Association between active commuting and incident cardiovascular disease, cancer, and mortality: Prospective cohort study. BMJ. 2017;357:j1456. http://dx.doi.org/10.1136/bmj.j1456

21. Macniven R, Bauman A, Abouzeid M. A review of population-based prevalence studies of physical activity in adults in the Asia-Pacific region. BMC Public Health. 2012;12(1):41. http://dx.doi.org/10.1186/1471-2458-12-41

22. Ogilvie D, Bull F, Cooper A, Rutter H, Adams E, Brand C, et al. Evaluating the travel, physical activity and carbon impacts of a 'natural experiment' in the provision of new walking and cycling infrastructure: Methods for the core module of the iConnect study. BMJ Open. 2012;2(1):e000694. http://dx.doi.org/10.1136/ bmjopen-2011-000694

23. Buehler R. Determinants of transport mode choice: A comparison of Germany and the USA. J Transp Geogr. 2011;19(4):644-57. http://dx.doi.org/10.1016/j.jtrangeo.2010.07.005

24. Lima JS, Ferrari GLM, Ferrari TK, Araujo TL, Matsudo VKR. Mudanças no deslocamento para o trabalho e na atividade física da população de três municípios da região de São Paulo nos anos de 2000 e 2010. Rev Bras Epidemiol. 2017;20(2):274-85. http://dx.doi.org/10.1590/1980-5497201700020008

25. Madeira MC, Siqueira FCV, Facchini LA, Silveira DS, Tomasi E, Thumé E, et al. Atividade física no deslocamento em adultos e idosos do Brasil: prevalências e fatores associados. Cad Saúde Pública. 2013;29(5):165-74. http://dx.doi.org/10.1590/S0102-311X2013000100019

26. Fajersztajn L, Veras M, Saldiva PHN. Como as cidades podem favorecer ou dificultar a promoção da saúde de seus moradores? Estud Av. 2016;30(86):7-27. http://dx.doi.org/10.1590/S0103-40142016.00100002 
27. Gordon-Larsen P, Boone-Heinonen JE, Sidney S, Sternfeld B, Jacobs DR, Lewis CE. Active commuting and cardiovascular disease risk: The CARDIA study. Arch Intern Med. 2009;169(13):1216-23. http://dx.doi.org/10. 1001/archinternmed.2009.163

28. Xu F, Delmonico MJ, Lofgren IE, Uy KM, Maris SA, Quintanilla D, et al. Effect of a Combined Tai Chi, resistance training and dietary intervention on cognitive function in obese older women. J Frailty Aging. 2017;6(3):167-71. http://dx.doi.org/10.14283/jfa.2017.16

29. Gayman AM, Fraser-Thomas J, Spinney JEL, Stone RC, Baker J. Leisure-time physical activity and sedentary behavior in older people: The influence of sport involvement on behavior patterns in later life. AIMS Public Health. 2017;4(2):171-88. http://dx.doi.org/10.3934/publichealth.2017.2.171

30. Myers J, McAuley P, Lavie CJ, Despres J-P, Arena R, Kokkinos P. Physical activity and cardiorespiratory fitness as major markers of cardiovascular risk: Their independent and interwoven importance to health status. Prog Cardiovasc Dis. 2015;57(4):306-14. http://dx.doi.org/10.1016/j.pcad.2014.09.011

31. Schmidt FM, Weschenfelder J, Sander C, Minkwitz J, Thormann J, Chittka T, et al. Inflammatory cytokines in general and central obesity and modulating effects of physical activity. PLOS One. 2015;10(3):e0121971. http://dx.doi.org/10.1371/journal.pone.0121971

32. Rovniak LS, Sallis JF, Saelens BE, Frank LD, Marshall SJ, Norman GJ, et al. Adults' physical activity patterns across life domains: Cluster analysis with replication. Health Psychol. 2010;29(5):496-505. http://dx.doi. org/10.1037/a0020428

Received: December 18, 2018

Final version: May 15, 2019

Approved: May 31, 2019 